\title{
Benedek József
}

\section{A társadalmi innováció társadalmi-gazdasági, fenntarthatósági feltételeinek vizsgálata - Észak-magyarországi viszonylatban}

Az alábbi tanulmány nem egy empirikus kutatás eredményeit közli, hanem összefoglaló jellegü szintézis, vagy „review” jellegü írás. Célja a társadalmi innováció Észak-magyarországi helyzetének értékelése, a releváns kutatási eredmények értelmezése és elhelyezése egy sajátos elméleti keretbe. Továbbá, tanulmányunkkal azt szeretnénk elérni, hogy a jobb megértést lehetövé tevö összegzést végezzünk az innováció regionális különbségeit meghatározó tényezőkől, ÉszakMagyarország példáján. A területi fókusz esetenként leszükül Borsod-Abaúj-Zemplén megyére, tekintettel arra, hogy elsösorban a Miskolci Egyetem Gazdaságtudományi Karán létrejött és müködö társadalmi innovációs mühely releváns eredményeit foglaljuk össze. A tanulmányban kitérünk az innováció és a társadalmi innováció keretfeltételeinek értékelésére, a fenntarthatóság és innováció összefüggéseinek feltárására, illetve az innovációs potenciál mérések módszertani és gyakorlati tanulságainak értékelésére is.

Kulcsszavak: társadalmi innováció, fenntarthatóság, innovációs potenciál JEL-kód: O35, Q01

https://doi.org/10.32976/stratfuz.2020.20

\section{Bevezető - az innovációt meghatározó általános tényezők}

Általánosan elfogadottá vált a társadalomtudományokban - hatalmas empirikus és elméleti anyaggal kellőképpen alátámasztva - az a nézet, hogy századunkban a társadalmi átalakulás és modernizáció, a gazdasági növekedés és fejlődés legfontosabb tényezője az innováció. Ezért vált a gazdaságpolitika egyik fő pillérévé a tudásalapú gazdaság támogatása, ennek részeként a kutatás-fejlesztési $(\mathrm{K}+\mathrm{F})$ tevékenységekbe, a vállalati innovációba irányuló beruházások növelése. A periférikus és félperiférikus térségek perspektívájából viszont nem megnyugtató tény, hogy a tudás és tudásalapú innováció termelése és ennek feltételei térben erőteljesen koncentrálódnak. Más szóval a tudás és az ehhez kapcsolódó, elsősorban technológiai innováció egy rendkívül szűkös gazdasági erőforrás. A gazdasági növekedés elméletek a technológiai tényezőt és a technológiai innovációt tekintik a változás és a fejlődés hajtómotorjának (Benedek, 2004; Benedek, 2006). A technológiai innovációra vonatkozó alapkérdés, hogy ez hogyan hat a regionális fejlődésre, illetve hogy tulajdonképpen hogyan megy végbe a technológiai fejlödés mechanizmusa? E kontextusban fontos megértenünk, hogy minden régió rendelkezik olyan jellegzetes ismeretek egy csomagjával, amelyek nagymértékben meghatározzák a régió helyét a nemzetközi munkamegosztásban. Ezek nemcsak müszaki jellegüek, hanem általában magukban foglalják a termelés, a vállalat szervezésében, a vállalaton belüli, a vállalatok közötti vagy az üzleti környezettel kialakított kapcsolatok fejlödése során felhalmozódott tapasztalatot (Benedek, 2006).

Az elmúlt két évtizedben az innováció-kutatások kiegészültek és folyamatosan bővültek a társadalmi dimenzióval. Ma számos szerző kiemelten foglalkozik a társadalmi innovációval (lásd Moulaert 2013; Benedek, Kocziszky, Veresné Somosi és Balaton 2016; Kocziszky és Szendi 2018). A társadalmi innováció lényegére és területi hatásaira vonatkozó általánosan elfogadott magyarázat hiányában korábbi írásunkban javasoltuk az ,új regionalizmus" keretében kidolgozott „Területi Innovációs Modell” (TIM) alkalmazását és fejlesztését (Benedek, Kocziszky, Veresné Somosi 2018). Ahogy már leírtuk, a TIM egyik elönye az, hogy multi-skalárisan vizsgálja meg az innováció térségi hatásait, elkülönítve két térségi szintet: a regionálist és a helyit (lokális). A társadalmi innováció vizsgálatára legalkalmasabb TIM modell, a GREMI által megalapozott innovációs környezet (uo.), mivel az utóbbi tartalmazza az innovációs folyamat második 
dimenzióját is (a gazdasági mellett), nevezetesen a szervezetek és a köztük lévő viszonyok innovációját, amelynek keretében a gazdaság-kultúra viszonyára, a gazdasági szervezés és termelés regionálisan differenciált módozatára, valamint az innovatív tevékenységekben résztvevő összes regionális szereplő közötti viszonyra kerül a hangsúly (uo.). A gazdasági elméletektől eltérően az innovatív környezet fogalma a tér és a gazdaság közötti dialektikus viszony értelmezésén alapszik: a tér alkotja a gazdasági folyamatok lezajlásának keretét, és ez utóbbiak döntő módon hozzájárulnak a tér átalakításához. A TIM szerint a gazdasági tevékenységek intézményesített kapcsolatokat hoznak létre, amelyek a helyi és regionális szociokulturális környezetben gyökereznek. Ez a területi paradigma hangsúlyozza a szomszédság és a távolság szerepét az innovatív környezet létrehozásában. Pontosabban a gazdasági tevékenység beágyazódása a helyi szociális viszonyok hálózatába a szociális integráció során történik. Az integráció során fontos bizalom kialakulását vagy elvesztését nem csupán a két szereplő közötti közvetlen viszony határozza meg, hanem a strukturális kontextus, amelyet az összes helyi vagy regionális szereplő alkot. Ezért gondoljuk azt, hogy a helyi és regionális kontextus kiemelkedő szerepet játszik az eltérő innovációs teljesítmény kialakulásában és ennek vizsgálata elngedhetetlen az innováció térbeli differenciálódásának megértéséhez.

A regionális tudományi szakirodalom (lásd a hazai szakirodalomban Lengyel és Rechnitzer, 2004) feltárta azokat a tényezőket, illetve azokat a gazdasági, területi, társadalmi és politikai összefüggéseket, amelyek meghatározzák a tudás és innováció területi koncentrációját, áttörö újdonságokra ezen a szakterületen nem számíthatunk a jövőben. Továbbra is az innováció kulcsparaméterei a földrajzi közelség vagy proximitás, az agglomeráció, a tudás szpillóver, a vállalati magatartás, az egyetemek és vállalatok közötti kapcsolatrendszer, a kormányzás minősége, a termékéletciklusban elfoglalt pozíció, a kockázati tőke, a regionális környezet vagy miliő, a munkaerő képzettségi szintje, a helyi és kormányzati támogatások stb. (Dőry és Rechnitzer, 2000; Benedek, 2004; Benedek, 2019).

Ehhez csupán néhány kritikai kommentet füznénk: 1. Bár az innováció-kutatás atyja, Joseph Schumpeter szerint a vállalkozók, az innovátorok újításai mozgatják a technikai változást és a gazdasági és regionális fejlődést (Schumpeter, 1980), az elmúlt néhány évtizedben a fent megfogalmazott kutatási egység eltolódott különböző aggregátumok vizsgálatára: vállalkozások, intézmények, hálózatok, régiók, országok. Mindez kétségtelenül fontos mozzanat az innováció újabb összefüggéseinek vizsgálatában, de ugyanakkor a kérdés lényegétől - az innovátorok és az innovációkat felhasználók személyétől - el is eltávolította a vizsgálatokat; 2 . Az igaz ugyan, hogy a jelentős innovációs miliők fejlett gazdaságok magterületein, nagyvárosi agglomerációkban koncentrálódnak, ahol nagyobb a kockázati tőke, több a $\mathrm{K}+\mathrm{F}$ beruházás, a magasan kvalifikált munkaerő, jelentősebb az információáramlás, de néhány újabb vizsgálat arra is rámutatott, hogy a kapcsolat nem ennyire egyértelmü, és hogy a fejlett gazdaságokban jelentős újítások periférikus térségekben is létrejönnek (Eder, 2018; Graffenberger és társai, 2019; Fitjar és Rodríguez-Pose, 2020). Ebben a folyamatban meghatározóvá válnak a periférikus térségek interregionális és nemzetközi kapcsolatai, amivel ellensúlyozni tudják a klasszikusnak mondható innovációs tényezők hiányát; 3 . Bár az innováció térbeli terjedését a standard szakirodalom a regionális gazdasági fejlödés fontos motorjának tartja, a hozzá füzött elvárásokat az empirikus vizsgálatok csak részben és kis léptékben igazolták. Nagyléptékü, regionális méretű innováció diffúzióra Kelet-Európában nincs példa, ami elsősorban arra vezethető vissza, hogy a periférikus régiók nem rendelkeznek kellő munkaerö-, kutatás-fejlesztési-, oktatási- és vállalati kapacítással arra, hogy saját, regionálisan beágyazódott és versenyképes innovációs rendszereket építsenek fel (Dőry és Rechnitzer, 2000).

A fenti kritikai megjegyzésekre igyekszünk a tanulmány további részeiben visszatérni. Ezek mellett, egy további fontos kérdés, amelyre a tanulmányban kitérünk: hogyan kapcsolódik az innováció a fenntarthatóság és a fenntartható fejlődés kérdéséhez? Bár ezzel a kapcsolatrendszerrel kevés tanulmány foglalkozik (lásd Karajz és Kis-Orlocki, 2019), alappal feltételezzük, hogy a fenntartható fejlődés négy dimenziójához (gazdasági, társadalmi, környezeti és területi) az innováció és különböző innovációtípusok - kifejezetten a társadalmi innováció is - 
szoros szálakon kapcsolódnak. Míg a klasszikusnak tekinthető technológiai- és gazdasági innovációkutatások a termelési módszerek tökéletesítésére és a természeti erőforrások kitermelésének és hasznosításának elősegítésére fókuszáltak, jelenleg, elsősorban a mérvadó nemzetközi szervezetek szintjén, ugyanolyan hangsúlyosak az innováció térbeli és időbeli összehangolásának, a társadalmi innováció hasznosulásának, az innováció fenntartható fejlődéshez való hozzájárulásának témaköre egyaránt.

A fenti kérdések különösen fontosak az Észak-magyarországi térségben, ahol jelentős mértékủ technológiai és innovációs lemaradás halmozódott fel nem csupán európai összehasonlításban, hanem szükebb, Kelet-európai, illetve hazai viszonylatban is (Benedek és Kocziszky, 2017; Kocziszky, 2021). A gazdasági szerkezetváltás negatív hatásait mintegy felerősítették a mély történelmi gyökerekkel rendelkező negatív demográfiai és munkaerőpiaci folyamatok (Beluszky, 2019; Lipták, Szendi és Musinszki, 2019), mozgásba hozva egy negatív kumulatív fejlődési hátrányt. Ilyen feltételek mellett jogosan fogalmazható meg az a kérdés: milyen eszközökkel támogatható a fejlődési pályaváltás Észak-Magyarországon? És a szakmai korrektség azt is megköveteli, hogy rákérdezzünk arra a lényeges kérdésre is, hogy egyáltalán lehetséges belátható időn belül, például egy generáció alatt, valamilyen fejlődési pályaváltás? Nem vállalkozunk arra, hogy egy szükös tanulmány kereteiben ilyen mélyenszántó kérdésekre minden részeltében reflektáljunk. Viszont a régióspecifikus keretfeltételeket összefoglaljuk és néhány nemzetközi példát is felhozunk, mindezt az innováció kutatásnak tér és innováció kölcsönhatásaira hangsúlyt tevő innováció-földrajzi perspektívából (Benedek, 2019).

\section{Az innováció társadalmi-gazdasági feltételei}

A szakirodalom általánosan elfogadja, hogy az innováció mértékét öt alapvető tényező kölcsönhatása határozza meg: az adott ország innovációs feltételei, azaz a nemzeti innovációs környezet, továbbá a felnőttek képzettségi szintje, az oktatási és kutatási infrastruktúra fejlettsége, a támogatási szakpolitika megfelelö cél- és eszközrendszere, az örökölt történelmi fejlődési pálya. Az utóbbi, az evolúciós gazdaságföldrajz szerint, behatárolja a jövőbeli fejlődés lehetőségeit. A továbbiakban a fenti tényezők rövid áttekintését nyújtjuk országosan, majd régióspecifikusan.

\section{A makroszintü innovációs keretfeltételek}

Gyengén teljesítő országos környezetben lehetetlen erös regionális innovációs rendszerek felépítése és müködtetése. Ezért nem meglepő, hogy - bár a $\mathrm{K}+\mathrm{F}$ - re fordított, GDP arányos kiadások 2007-hez képest növekedtek (0,96\%-ról 1,53\%-ra 2018-ban, az Eurostat szerint) Magyarország mérsékelt innovátornak számít, és regionális léptékben sincs az országos átlagnál jobban teljesítő térség, a fövárost nem számítva. Ezzel az ország EU-s viszonylatban jobban szerepel mint a „lemaradó innovátor” kategóriába tartozó Bulgária vagy Románia, illetve az elmúlt években sikerült megelőznie Horvátországot, Lengyelországot és Litvániát is, de az uniós átlagtól továbbra is jelentősen lemarad, illetve jelentős mértékben leszakadt a korábban hasonló innovációs képességekkel rendelkező Észtországról, amely 2018-ban első alkalommal bekerült a vezető innovátorok közé (EB, 2019). Az 1. táblázat összefoglalja az ország legfontosabb innovációs dimenzióit és mutatóit, az Európai Innovációs Eredménytábla alapján. Jól követhető a 2011 és 2018 között mért, az EU-átlaghoz viszonyított és az innovációs index értékében kifejezett általános előrehaladás. Ugyanakkor világosan körvonalazódnak a nemzeti innovációs rendszer erős és gyenge pontjai. Jelentős elmozdulást csupán egy dimenzióban látunk, az innováció-barát környezet fejlődésében, illetve ennek keretében a szélessávú internet penetrációjának látványos növekedése okozta e jelentős fejlődést, tehát tulajdonképpen az innováció keretfeltételei nemcsak javultak, hanem ebben a dimenzióban jóval felülteljesítik az EU-s átlagot. Az Innovációs Eredménytábla dimenzióinak többségében mérsékelt fejlődés állapítható meg, míg néhány dimenzió tekintetében visszaesés tapasztalható, európai összehasonlításban. Az utóbbihoz tartoznak az emberi erőforrások, a hálózatok-kapcsolatok, a foglalkoztatási hatások és az 
értékesítési hatások dimenziói. Ebből három dimenzió (emberi erőforrások, és a két hatásdimenzió) részben tükrözik a magyar gazdaság nemzetközi munkamegosztásban elfoglalt és konszolidálni látszó folyamatát. Éspedig a magyar gazdaság elsősorban munkaintenzív folyamatokra szakosodott, ez export jelentős része az alacsony termelési költségek komparatív előnyeit kihasználó tevékenységekből származik. Különösen az értékesítési hatások visszaesése kiemelkedő, azért mert míg 2011-ben ebben a dimenzióban Magyarország uniós átlag felett teljesített, ez a kép mára már teljesen megfordult, és a teljes dimenzióban uniós átlag alatti a teljesítmény. Amennyiben megvizsgáljuk a dimenziót kifejező három mutatót, jól látszik, hogy a jelentős visszaesést egy mutató váltotta ki, éspedig a cégek számára új innovációk értékesítése, ami a vállalatok innovációs tevékenységének gyengülését jelzi, paradox módon, hisz feljebb láthattuk, hogy az innováció-barát környezet dimenzió látványosan fejlődött az elmúlt évtized alatt, meghaladva az uniós átlagot.

A foglalkoztatási hatások is némileg paradox és ellentmondásosnak ítélhető trendeket vetítenek ki: egyrészt az ország továbbra is kiemelkedően teljesít (EU-s átlag felett) a közepes és high-tech termékek exportját illetően, másrészt viszont szerény és negatív trenddel rendelkezik a tudásintenzív szektorok foglalkoztatási aránya. Ugyanilyen kettősség állapítható meg a „Nem $\mathrm{K}+\mathrm{F}$ vállalati innovációs kiadások" (vállalati beruházások dimenzió) uniós átlag feletti értéke és pozitív trendje, valamint az ,állam $\mathrm{K}+\mathrm{F}$ üzleti társfinanszírozása” (hálózatok-kapcsolatok dimenzió) uniós átlag alá eső értéke és negatív trendje között. Kétségtelenül a fenti ellentmondások egy jobban koordinált és célirányosabb szakpolitikai beavatkozás hiányára is utalnak.

A hálózatok-kapcsolatok dimenzióban tapasztalt visszaesés azért érinti érzékenyen az országos innovációs rendszert, mert, ahogy a bevezetőben már utaltam rá, a fél-periférikus térségek egyik kitörési lehetősége az interregionális kapcsolatok és nemzetközi hálózatok építésében és fejlesztésében rejtőzik.

Továbbá a gyenge pontokhoz soroljuk azokat a dimenziókat és mutatókat, ahol, bár volt pozitív elmozdulás 2011-hez képest, az EU-s átlaghoz viszonyított lemaradás továbbra is jelentős. Ez a megállapítás érvényes az innovátorok, szellemi tulajdon, finanszírozás és támogatás, emberi erőforrások, attraktív kutatási rendszer dimenziókra. Különösen nagy a leszakadás (az uniós átlag 25-31\%-án) állami $\mathrm{K}+\mathrm{F}$ kiadások, az innovációkat végrehajtó $\mathrm{KKV}-\mathrm{k}$ és az új védett minták tekintetében, ami már egymagában is jelzi az állami támogatási priorítások átfogalmazásának szükségességét és irányát.

1.táblázat: Magyarország innovációs eredménytáblája, 2019.

\begin{tabular}{|l|c|c|}
\hline Dimenzió/mutató & $\begin{array}{c}\text { EU 2011-es } \\
\text { atlagához képest }\end{array}$ & $\begin{array}{c}\text { EU 2018-as } \\
\text { átlagához képest }\end{array}$ \\
\hline Innovációs index & $\mathbf{6 6 . 2}$ & $\mathbf{6 9 . 0}$ \\
\hline Emberi erőforrások & $\mathbf{5 7 . 0}$ & $\mathbf{5 3 . 7}$ \\
\hline Újonnan doktori fokozatot szerzők száma & 46.2 & 58.2 \\
\hline Felsőfokú képzettségüek aránya & 61.9 & 50.0 \\
\hline Élethosszig tartó tanulás & 62.5 & 53.1 \\
\hline Attraktív kutatási rendszer tudományos & $\mathbf{3 7 . 1}$ & $\mathbf{5 5 . 9}$ \\
\hline $\begin{array}{l}\text { Nemzetközi társszerzős tún } \\
\text { publikációk }\end{array}$ & 51.2 & 71.8 \\
\hline Nagy idézettségű publikációk & 35.2 & 50.2 \\
\hline Külföldi doktori hallgatók & 30.5 & 54.4 \\
\hline Innováció-barát környezet & $\mathbf{6 8 . 8}$ & $\mathbf{1 4 4 . 7}$ \\
\hline Szélessávú internet penetráció & 88.9 & 211.1 \\
\hline Vállalkozások & 55.0 & 99.5 \\
\hline Finanszírozás és támogatás & $\mathbf{3 6 . 5}$ & $\mathbf{4 6 . 2}$ \\
\hline Állami K+F kiadások & 47.7 & 30.9 \\
\hline
\end{tabular}




\begin{tabular}{|l|c|c|}
\hline Kockázati tőke ráfordítások & 23.2 & 64.2 \\
\hline Vállalati beruházások & $\mathbf{7 4 . 3}$ & $\mathbf{9 8 . 0}$ \\
\hline Üzleti szektor K+F kiadásai & 56.2 & 82.8 \\
\hline Nem K+F innovációs kiadások & 104.2 & 122.5 \\
\hline ICT képzést nyujtó vállalatok & 60.0 & 86.7 \\
\hline Innovátorok & $\mathbf{2 8 . 9}$ & $\mathbf{3 0 . 9}$ \\
\hline $\begin{array}{l}\text { Termék/folyamat innovációt végrehajtó } \\
\text { KKV-k }\end{array}$ & 33.0 & 37.2 \\
\hline $\begin{array}{l}\text { Marketing/szervezeti innovációt végrehajtó } \\
\text { KKV-k }\end{array}$ & 34.0 & 27.1 \\
\hline In-house innovációt végrehajtó KKV-k & 19.5 & 28.3 \\
\hline Hálózatok, kapcsolatok & $\mathbf{8 1 . 6}$ & $\mathbf{5 7 . 1}$ \\
\hline Kooperációkban résztvevő innovatív KKV-k & 59.7 & 46.7 \\
\hline Közszolgálati és magán közös publikációk & 45.6 & 70.3 \\
\hline Állami K+F üzleti társfinanszírozása & 113.2 & 58.9 \\
\hline Szellemi tulajdon & $\mathbf{3 6 . 6}$ & $\mathbf{4 0 . 1}$ \\
\hline PCT szabadalmak & 38.4 & 35.1 \\
\hline Új kereskedelmi márkák & 51.9 & 63.5 \\
\hline Védett minták & 22.1 & 26.1 \\
\hline Foglalkoztatási hatások & $\mathbf{1 2 7 . 1}$ & $\mathbf{1 2 4 . 2}$ \\
\hline $\begin{array}{l}\text { Foglalkoztatás } \\
\text { tevékenységekben }\end{array}$ & 89.7 & 75.6 \\
\hline $\begin{array}{l}\text { Foglalkoztatás } \\
\text { vállalatokban gyorsan }\end{array}$ & 154.0 & 159.2 \\
\hline Értékesítési hatások növekedő & $\mathbf{1 1 1 . 1}$ & $\mathbf{8 4 . 1}$ \\
\hline Közepes és high-tech termékek exportja & 142.3 & 139.7 \\
\hline Tudásintenzív szolgáltatások exportja & 61.4 & 61.1 \\
\hline Cég számára új innovációk értékesítése & 131.4 & 44.6 \\
\hline
\end{tabular}

Forrás: saját szerkesztés, EB (2019) alapján

A jövőben látványos, áttörő változás nem várható, hisz az ország 1,53\%-ot, az uniós átlagnál lényegesen kevesebbet fordít a $\mathrm{K}+\mathrm{F}$ költségvetési támogatására (2,19\% az EU 27-ben, 2018-ban). Az állam, a magánvállalkozások szerény $\mathrm{K}+\mathrm{F}$ ráfordításával magyarázható a szerény innovációs teljesítmény. Ez nyilván csupán az érem egyik oldala, ehhez adódik a $\mathrm{K}+\mathrm{F}$ tevékenységek, és általánosan az innovációs infrastruktúra és alapfeltételek hiányosságai, illetve a jelentős innovátorokhoz viszonyított elmaradottsága. Ezért nem választható el az innovációpolitika a társadalom modernizációjától és az ezt megtámasztó ágazati politikától (oktatáspolitika, gazdaságpolitka, lakáspolitika stb.). Ilyen kedvezőtlen makrofeltételek között, nagyon beszükülnek a magyarországi periférikus régiók és térségek kitörési lehetőségei.

\section{Társadalmi innováció és regionális gazdasági fejlödés}

Bár több tanulmányban a periférikus régiók felzárkózásában a társadalmi innováció alternatív megoldásként megfogalmazódik (Kocziszky és Szendi 2018; Szendi 2018), mindeddig nem körvonalazódott kellőképpen az a konkrét hatásmechanizmus, amellyel a társadalmi innováció gazdasági növekedést, hosszabb távon pedig konvergenciát és felzárkózást generálhatna. Valószínübb hipotézisnek tủnik, hogy a társadalmi innováció tulajdonképpen nem az innováció egyéb formáinak (üzleti, technológiai, tudományos) az alternatívája, hanem hogy ez szorosan kapcsolódik, együtt mozog statisztikailag a többi innováció típussal. Ezen feltételezés területi szempontból azzal a következménnyel jár, hogy azok a térségek képesek jelentős társadalmi innovációt generálni, amelyek kiemelkednek az innovációs tevékenység egyéb formáiban is, és 
fordítva, gyenge üzleti-, technológiai- és tudományos innovációt létrehozó régiók társadalmi innovációja sem jelentős. Ugyanakkor, valószínűbbnek tartjuk a társadalmi innováció mérhetően pozitív szerepét néhány kistérség, település fejlődésében, de nagyobb területi szinten, mintegy összregionális, aggregált területi szinten, a társadalmi innováció pozitív hatásait az eddigi empirikus vizsgálatok nem igazolták (Cebotari és Benedek, 2017; Benedek, Sebestyén és Bartók, 2018).

Ezért tartjuk fontosnak regionális szinten általánosan összefoglalni az innovációs feltételek és teljesítmény területileg differenciált mutatóit (2., 3., 4., 5. táblázatok). Így lehetővé válik a regionális innovációs rendszerek lehatárolása, egyes térségek innováció-alapú besorolása és meghatározása. Az előző bekezdésben megfogalmazott hipotézis szerint a társadalmi innováció intenzítása és hatásai ott lesz a legjelentősebb, ahol egy regionális innovációs rendszer körvonalazható. Végezetül, de nem utolsó sorban, a fenti területi és innovációs mátrixban jobban láthatóvá válnak az Észak-magyarországi régió fejlődési, fejlesztési és pályaváltási lehetőségei is.

2. táblázat: NUTS 2 régiók gazdasági és innovációs teljesítménye

\begin{tabular}{|l|c|c|c|c|c|}
\hline & $\begin{array}{c}\text { Egy före jutó } \\
\text { GDP, pps, 2018 }\end{array}$ & $\begin{array}{c}\text { K+F kiadások, } \\
\text { GDP \%-ban, } \\
2017\end{array}$ & $\begin{array}{c}\text { Kutatók, } \\
\text { foglalkoztatot } \\
\text { tak } \\
\text { összlétszámáb } \\
\text { ól, \%, 2017 }\end{array}$ & $\begin{array}{c}\text { Humán } \\
\text { eröforrások } \\
\text { tudományban és } \\
\text { technológiában, } \\
\%, 2019^{*}\end{array}$ & $\begin{array}{c}\text { Felsöoktatásban } \\
\text { hallgatók } \\
\text { száma/1000 lakos, } \\
2018\end{array}$ \\
\hline Budapest & 44600 & 2.25 & 2.12 & 60.3 & 83,4 \\
\hline Pest & 17400 & 0.6 & 0.26 & 39.7 & 10,6 \\
\hline $\begin{array}{l}\text { Közép- } \\
\text { Dunántúl }\end{array}$ & 20200 & 1.04 & 0.40 & 32.8 & 8,5 \\
\hline $\begin{array}{l}\text { Nyugat- } \\
\text { Dunántúl }\end{array}$ & 22200 & 0.63 & 0.25 & 32.0 & 15,4 \\
\hline Dél-Dunántúl & 15100 & 0.68 & 0.26 & 29.1 & 26,2 \\
\hline $\begin{array}{c}\text { Észak- } \\
\text { Magyarország }\end{array}$ & $\mathbf{1 5 1 0 0}$ & $\mathbf{0 . 4 7}$ & $\mathbf{0 . 2 0}$ & $\mathbf{2 8 . 1}$ & $\mathbf{1 5 , 1}$ \\
\hline Észak-Alföld & 14100 & 0.94 & 0.26 & 29.0 & 21,5 \\
\hline Dél-Alföld & 16000 & 1.07 & 0.36 & 31.0 & 22,8 \\
\hline Magyarország & 21898 & 1.33 & 0.88 & 38.2 & 29 \\
\hline
\end{tabular}

*15-74 év közötti, felsőfokú végzéssel és tudományban vagy technológiában foglalkozatottak részaránya

Forrás: Eurostat, saját szerkesztés

A 2. és 3. táblázatokban összeállított, innovációs mutatókat felsorakoztató statisztika alapján Magyarország egyetlen NUTS 2-es szintü innovatív régiója Közép-Magyarország. Az utóbbiban Budapest lényegesen jobban teljesít, mint Pest megye, tehát alapjában véve Magyarországon is egy olyan, Közép-Kelet-európai országokhoz hasonló, általános trend alakult ki, amely kedvez az innovációs tényezők fővárosi koncentrációjának. Ennek megfelelően, Budapest innovációs infrastruktúrája és teljesítménye messze fölemelkedik az egyes megyék szintjén. Továbbá világosan látszik a táblázatokban, hogy a jó innovációs teljesítmény nem minden esetben jár megfelelően magas gazdasági teljesítménnyel. Például az egyébként magyarországi viszonylatban elfogadható innovációs mutatókkal rendelkező Dél-Alföld egy före jutó GDP-jét meghaladja mindkét - gyengébb innovációs teljesítménnyel rendelkező - nyugatmagyarországi régió. Ez a helyzet arra mutat rá, hogy az innováció formális mutatói elsősorban a kódolt tudásállományhoz kapcsolható, míg az innováció legfontosabb forrása a hallgatólagos tudás terjedéséhez kapcsolódó túlcsordulás hatásokban található meg (Malmberg és Maskell, 2002; Cebotari és Benedek, 2017).

Az Észak-magyarországi régió helyzetét illetően, a 2. táblázatban világosan látszik a térség marginális, periférikus helyzete. Gyakorlatilag mindegyik összehasonlításra felhasznált mutató tekintetében a legrosszabban teljesítő régió: legalacsonyabb a $\mathrm{K}+\mathrm{F}$ kiadások aránya a 
GDP-ből, legalacsonyabb a kutatók részaránya a foglalkoztatottak összlétszámából, legalacsonyabb a humán erőforrások részaránya a tudományban és technológiában. Csupán az ezer lakosra jutó felsőoktatásban hallgatók létszámát illetően előz megy Észak-Magyarország két régiót, de a mutató értéke (15,1/1000 lakos) így is csupán fele az országos átlagnak.

3. táblázat: Régiók gazdasági és innovációs súlya

\begin{tabular}{|l|c|c|c|c|}
\hline & $\begin{array}{c}\text { Régiók GDP } \\
\text { részesedése, \%, } \\
2018\end{array}$ & $\begin{array}{c}\text { Régiók } \\
\text { részesedése } \\
\mathrm{K}+\mathrm{F} \\
\text { foglalk., } \\
2015\end{array}$ & $\begin{array}{c}\text { Régiók } \\
\text { részesedése K+F } \\
\text { ráfordításokból, } \\
\%, 2015\end{array}$ & $\begin{array}{c}\text { Felsőfokú } \\
\text { végzettséggel } \\
\text { rendelkezők aránya } \\
\text { a 25-64 évesek } \\
\text { közül, \%, 2017 }\end{array}$ \\
\hline $\begin{array}{c}\text { Közép- } \\
\text { Magyarország }\end{array}$ & 46.7 & 61.8 & 64.6 & 35.6 \\
\hline $\begin{array}{c}\text { Közép- } \\
\text { Dunántúl }\end{array}$ & 10.2 & 6.1 & 7.1 & 20.1 \\
\hline $\begin{array}{c}\text { Nyugat- } \\
\text { Dunántúl }\end{array}$ & 10.1 & 4.5 & 4.7 & 20.8 \\
\hline Dél-Dunántúl & 6.2 & 5.0 & 1.9 & 18.4 \\
\hline $\begin{array}{c}\text { Észak- } \\
\text { Magyarország }\end{array}$ & $\mathbf{8 . 0}$ & $\mathbf{4 . 0}$ & $\mathbf{2 . 8}$ & $\mathbf{1 7 . 5}$ \\
\hline Észak-Alföld & 9.4 & 8.4 & 7.7 & 17.4 \\
\hline Dél-Alföld & 9.3 & 10.1 & 11.2 & 19.6 \\
\hline
\end{tabular}

Forrás: Eurostat, saját szerkesztés.

A 3. táblázatban követhetjük a NUTS 2 régiók gazdasági (GDP) és innovációs súlyát az országos összértékekből. Az adatok azt mutatják, hogy míg a gazdasági teljesítmény és a humántőke területi megoszlása kiegyensúlyozottabb, a $\mathrm{K}+\mathrm{F}$ tevékenységek térben erősen koncentrálódnak. Például Magyarországon a $\mathrm{K}+\mathrm{F}$ foglalkoztatottak több mint $60 \%$-a a fóvárosi régióban él. Ez megyék szintjén a fővárosi térségeken kívül Csongrád megyében jelent átlagnál jelentősen magasabb értékeket. Csongrád megyében újból Szeged kiemelkedő kutatási infrastruktúrájával magyarázható a helyzet.

4.táblázat: Megyék részesedése a $\mathrm{K}+\mathrm{F}$ foglalkoztatottakból

\begin{tabular}{|l|c|c|c|c|c|c|c|c|c|c|c|c|}
\hline Megye & 2005 & 2006 & 2007 & 2008 & 2009 & 2010 & 2011 & 2012 & 2013 & 2014 & 2015 & 2016 \\
\hline Budapest & 51,36 & 52,19 & 53,79 & 53,48 & 52,98 & 53,42 & 53,44 & 52,03 & 52,33 & 54,06 & 56,10 & 55,67 \\
\hline Pest & 3,98 & 3,82 & 4,10 & 3,92 & 4,23 & 4,54 & 4,30 & 4,55 & 4,73 & 5,65 & 5,74 & 5,29 \\
\hline Fejér & 2,24 & 2,68 & 2,14 & 2,41 & 2,27 & 1,89 & 1,87 & 2,35 & 2,26 & 2,15 & 1,92 & 1,95 \\
\hline $\begin{array}{l}\text { Komáro } \\
\text { m- } \\
\begin{array}{l}\text { Esztergo } \\
\text { m }\end{array}\end{array}$ & 0,79 & 0,73 & 0,69 & 0,65 & 0,75 & 1,11 & 1,18 & 1,46 & 1,18 & 1,16 & 1,32 & 1,15 \\
\hline $\begin{array}{l}\text { Veszpré } \\
\text { m }\end{array}$ & 2,31 & 2,18 & 2,39 & 2,12 & 2,21 & 2,05 & 2,48 & 3,29 & 3,03 & 2,77 & 2,87 & 3,02 \\
\hline $\begin{array}{l}\text { Györ- } \\
\text { Moson- } \\
\text { Sopron }\end{array}$ & 3,18 & 3,51 & 3,56 & 3,67 & 4,02 & 4,22 & 4,18 & 3,48 & 4,12 & 3,77 & 3,14 & 3,03 \\
\hline Vas & 0,94 & 1,14 & 1,16 & 1,18 & 1,09 & 0,92 & 0,90 & 0,82 & 1,04 & 0,96 & 0,97 & 1,06 \\
\hline Zala & 0,56 & 0,55 & 0,70 & 0,69 & 0,80 & 0,69 & 0,88 & 0,79 & 0,62 & 0,59 & 0,41 & 0,52 \\
\hline Baranya & $\mathbf{7 , 3 6}$ & $\mathbf{7 , 1 8}$ & 4,70 & 5,90 & 5,19 & 4,32 & 4,41 & 4,30 & 3,97 & 3,58 & 3,48 & 3,67 \\
\hline Somogy & 1,03 & 0,98 & 1,06 & 1,07 & 0,81 & 1,24 & 0,96 & 1,03 & 1,19 & 1,00 & 1,09 & 1,19 \\
\hline Tolna & 0,46 & 0,46 & 0,37 & 0,41 & 0,33 & 0,39 & 0,35 & 0,40 & 0,51 & 0,42 & 0,40 & 0,36 \\
\hline $\begin{array}{l}\text { Borsod- } \\
\text { Abaúj- } \\
\text { Zemplén }\end{array}$ & $\mathbf{3 , 0 3}$ & $\mathbf{3 , 0 6}$ & $\mathbf{3 , 0 6}$ & $\mathbf{2 , 8 2}$ & $\mathbf{2 , 9 0}$ & $\mathbf{2 , 9 2}$ & $\mathbf{2 , 7 5}$ & $\mathbf{2 , 8 3}$ & $\mathbf{2 , 7 1}$ & $\mathbf{2 , 3 2}$ & $\mathbf{2 , 4 2}$ & $\mathbf{2 , 2 0}$ \\
\hline Heves & $\mathbf{1 , 3 7}$ & $\mathbf{1 , 5 6}$ & $\mathbf{1 , 7 7}$ & $\mathbf{1 , 7 1}$ & $\mathbf{1 , 9 8}$ & $\mathbf{1 , 8 6}$ & $\mathbf{1 , 6 6}$ & $\mathbf{1 , 6 3}$ & $\mathbf{1 , 9 6}$ & $\mathbf{1 , 6 9}$ & $\mathbf{1 , 4 0}$ & $\mathbf{1 , 3 3}$ \\
\hline
\end{tabular}




\begin{tabular}{|c|c|c|c|c|c|c|c|c|c|c|c|c|}
\hline Nógrád & 0,06 & 0,14 & 0,13 & 0,21 & $\mathbf{0 , 3 0}$ & 0,34 & 0,34 & 0,31 & 0,28 & 0,22 & 0,22 & 0,37 \\
\hline $\begin{array}{l}\text { Hajdú- } \\
\text { Bihar }\end{array}$ & 7,27 & 6,28 & 7,05 & 7,06 & 7,09 & 7,09 & 7,08 & 7,43 & 6,91 & 6,91 & 6,89 & 7,14 \\
\hline $\begin{array}{l}\text { Jász- } \\
\text { Nagykun } \\
\text {-Szolnok }\end{array}$ & 0,91 & 0,89 & 0,95 & 0,93 & 0,73 & 0,87 & 0,96 & 0,91 & 0,66 & 0,56 & 0,54 & 0,55 \\
\hline $\begin{array}{l}\text { Szabolcs } \\
- \\
\text { Szatmár- } \\
\text { Bereg }\end{array}$ & 1,62 & 1,73 & 1,90 & 1,82 & 1,66 & 1,43 & 1,27 & 1,39 & 1,03 & 0,98 & 0,95 & 1,11 \\
\hline $\begin{array}{l}\text { Bács- } \\
\text { Kiskun }\end{array}$ & 2,33 & 2,40 & 2,24 & 1,69 & 1,84 & 2,01 & 2,18 & 2,30 & 2,44 & 1,82 & 1,38 & 1,63 \\
\hline Békés & 0,83 & 0,93 & 0,88 & 0,67 & 0,60 & 0,61 & 0,61 & 0,65 & 0,85 & 0,77 & 0,62 & 0,48 \\
\hline $\begin{array}{l}\text { Csongrá } \\
\text { d }\end{array}$ & 8,39 & 7,58 & 7,37 & 7,61 & 8,22 & 8,07 & 8,20 & 8,04 & 8,18 & 8,62 & 8,14 & 8,29 \\
\hline
\end{tabular}

Forrás: Eurostat, saját szerkesztés

A 4. és 5. táblázatokban követhetjük két innovációs mutató (megyék részesedése $\mathrm{K}+\mathrm{F}$ foglalkoztatottakból, illetve az egy lakosra jutó $\mathrm{K}+\mathrm{F}$ költségek) területi megoszlását NUTS 3 , azaz a megyék szintjén. Sajnos a szabadalmak regionális összehasonlításokról az elmúlt évek során a szakirodalom fokozatosan lemondott, az adatok elérhetetlensége miatt. Így, az Eurostat csak 2012-ig közöl regionális bontású szabadalmi adatokat. Országos léptékben, a KSH szerint a szabadalmak száma folyamatosan növekedett, igaz, a növekedés üteme nem kiemelkedő. Feltételezzük, hogy a növekedés nagyobb hányada, a korábbi területi mintákat követve, a föváros és tradicionális egyetemvárosok által polarizált megyék.

4.táblázat: Megyék részesedése a $\mathrm{K}+\mathrm{F}$ ráfordításokból

\begin{tabular}{|c|c|c|c|c|c|c|c|c|c|c|c|c|}
\hline Megye & 2005 & 2006 & 2007 & 2008 & 2009 & 2010 & 2011 & 2012 & 2013 & 2014 & 2015 & 2016 \\
\hline Budapest & $\begin{array}{c}63,2 \\
7 \\
\end{array}$ & $\begin{array}{c}64,8 \\
1 \\
\end{array}$ & $\begin{array}{c}60,2 \\
7\end{array}$ & $\begin{array}{c}60,6 \\
8\end{array}$ & $\begin{array}{c}60,5 \\
1\end{array}$ & $\begin{array}{c}60,8 \\
7\end{array}$ & $\begin{array}{c}61,5 \\
7\end{array}$ & $\begin{array}{c}58,5 \\
9\end{array}$ & $\begin{array}{c}57,3 \\
6\end{array}$ & $\begin{array}{c}59,1 \\
9\end{array}$ & $\begin{array}{c}58,9 \\
6\end{array}$ & $\begin{array}{c}63,9 \\
2\end{array}$ \\
\hline Pest & 3,53 & 3,73 & 4,35 & 3,98 & 3,79 & 4,44 & 3,58 & 3,38 & 3,65 & 4,46 & 4,91 & 4,08 \\
\hline Fejér & 2,08 & 2,11 & 2,55 & 2,59 & 2,36 & 2,07 & 1,91 & 2,14 & 2,23 & 2,27 & 2,09 & 2,00 \\
\hline $\begin{array}{l}\text { Komárom- } \\
\text { Esztergom }\end{array}$ & 0,36 & 0,48 & 0,26 & 0,45 & 0,59 & 0,80 & 0,84 & 1,22 & 1,82 & 1,98 & 1,35 & 0,96 \\
\hline Veszprém & 2,21 & 2,18 & 2,45 & 2,62 & 2,55 & 2,44 & 2,79 & 4,15 & 4,40 & 3,72 & 3,61 & 4,20 \\
\hline $\begin{array}{l}\text { Győr- } \\
\text { Moson- } \\
\text { Sopron }\end{array}$ & 2,55 & 3,01 & 2,91 & 3,62 & 3,01 & 3,92 & 4,03 & 3,19 & 3,95 & 3,38 & 2,92 & 3,29 \\
\hline Vas & 0,42 & 0,64 & 2,71 & 1,39 & 1,20 & 0,68 & 0,98 & 1,09 & 1,13 & 1,36 & 1,53 & 1,44 \\
\hline Zala & 0,27 & 0,31 & 0,41 & 0,36 & 0,45 & 0,40 & 0,42 & 0,48 & 0,32 & 0,25 & 0,17 & 0,25 \\
\hline Baranya & 2,41 & 2,31 & 1,93 & 1,57 & 1,79 & 1,73 & 2,42 & 3,65 & 2,30 & 1,70 & 1,24 & 1,11 \\
\hline Somogy & 0,58 & 0,44 & 0,39 & 0,48 & 0,51 & 0,67 & 0,62 & 0,75 & 0,76 & 0,61 & 0,45 & 0,48 \\
\hline Tolna & 0,12 & 0,16 & 0,15 & 0,11 & 0,12 & 0,15 & 0,17 & 0,23 & 0,39 & 0,38 & 0,17 & 0,22 \\
\hline $\begin{array}{l}\text { Borsod- } \\
\text { Abaúj- } \\
\text { Zemplén }\end{array}$ & 2,03 & 1,99 & 2,16 & 2,01 & 2,14 & 2,30 & 2,13 & 2,24 & 2,42 & 2,42 & 1,72 & 1,39 \\
\hline Heves & 0,79 & 1,04 & 1,15 & 1,33 & 1,67 & 1,10 & 0,99 & $\mathbf{0 , 8 7}$ & 1,04 & 1,26 & $\mathbf{0 , 8 6}$ & 0,67 \\
\hline Nógrád & 0,02 & 0,06 & 0,10 & 0,10 & 0,18 & 0,26 & $\mathbf{0 , 3 2}$ & $\mathbf{0 , 3 6}$ & $\mathbf{0 , 3 9}$ & $\mathbf{0 , 2 7}$ & 0,22 & $\mathbf{0 , 3 5}$ \\
\hline $\begin{array}{l}\text { Hajdú- } \\
\text { Bihar }\end{array}$ & 7,10 & 6,05 & 6,13 & 7,51 & 7,87 & 7,04 & 6,50 & 6,67 & 6,35 & 6,79 & 6,36 & 5,68 \\
\hline $\begin{array}{l}\text { Jász- } \\
\text { Nagykun- } \\
\text { Szolnok } \\
\end{array}$ & 0,77 & 0,80 & 1,33 & 1,28 & 1,06 & 1,06 & 0,90 & 1,12 & 1,39 & 0,78 & 0,64 & 0,80 \\
\hline $\begin{array}{l}\text { Szabolcs- } \\
\text { Szatmár- } \\
\text { Bereg }\end{array}$ & 0,74 & 0,76 & 0,87 & 0,96 & 0,85 & 0,72 & 0,58 & 0,90 & 1,05 & 0,37 & 0,59 & 0,61 \\
\hline
\end{tabular}




\begin{tabular}{|l|c|c|c|c|c|c|c|c|c|c|c|c|}
\hline $\begin{array}{l}\text { Bács- } \\
\text { Kiskun }\end{array}$ & 1,64 & 1,89 & 2,51 & 2,11 & 1,64 & 1,92 & 2,24 & 2,52 & 2,89 & 2,41 & 2,56 & 2,05 \\
\hline Békés & 0,52 & 0,60 & 0,57 & 0,40 & 0,50 & 0,50 & 0,40 & 0,46 & 0,55 & 0,68 & 0,67 & 0,25 \\
\hline Csongrád & 4,91 & 4,63 & 4,64 & 4,46 & 5,44 & 5,19 & 4,99 & 4,46 & 4,33 & 4,48 & 7,83 & 4,94 \\
\hline
\end{tabular}

Forrás: Eurostat, saját szerkesztés

A 2. táblázatban található adatok alapján felvázolt összefüggések érvényesek a megyei szinten is, de a megoszlás területileg differenciáltabb. Így, a fővárosi térség mellett (Budapest és Pest megye) világosabban körvonalazódik öt megye, ahol jelentősebb az innováció, azaz magasabb a részesedésük a $\mathrm{K}+\mathrm{F}$ foglalkoztatottakból és/vagy a $\mathrm{K}+\mathrm{F}$ ráfordításokból is: HajdúBihar, Csongrád, Baranya, Veszprém és Győr-Moson-Sopron. Az első három megye jelentős egyetemi központokkal rendelkezik: Debrecen, Szeged és Pécs. Az utóbbiaknak kiemelkedő szerep jut az innovatív régiók fejlődésében, mert jelentős tudományos és technológiai innovációs tevékenységgel rendelkeznek, magasan képzett munkaerőt képeznek, jelentős hazai és nemzetközi hírnévvel rendelkeznek, és általában pozitív a róluk alkotott külső kép, az úgynevezett imázs. Ezért gyakorlatilag az egyetemek fejlesztését célzó befektetések az innovációs ipar vonzásának egyik eszközét képezik. Mindez azonban nem feltétlenül eredményezi az innovatív cégek megjelenését, mivel a kutatási eredmények és a képzett munkaerő nagyobb távolságból is hozzáférhető. Az egyetemek és ipar közötti társulások elősegítik ezt a folyamatot, elsősorban a városi agglomerációkban.

Továbbá, a fent említett megyék jelentős fejlesztéseket valósítottak meg ipari parkok és technológiai parkok létrehozásával, ami versenyképességük és innovatív kapacitásuk további megerősítéséhez vezetett. Gyengébben fejlett régiók - így Észak-Magyarország három megyéje sem - nem tudták biztosítani az ilyen típusú fejlesztésekhez szükséges feltételeket, elsősorban korlátozott erőforrásaik miatt. A három Észak-magyarországi megye országos innovációs súlya szerénynek ítélhető, és a táblázatokban lévő adatsorok ezen súly folyamatos csökkenését mutatják, ami egyértelmủen bizonyítja folyamatos marginalizálódásukat a magyar gazdasági- és innovációs térben.

Mindehhez hozzá kell még füzni, hogy jóllehet a szakirodalomban általános az egyetértés a technológiai tényező (főként az innovációk) döntő szerepéről a regionális fejlesztésben, egyelőre nem létezik egy általánosan elfogadott magyarázat a régiók innovációs képességében megmutatkozó különbségekre (Benedek 2004; Benedek 2006). A tekintélyes mennyiségü empirikus megfigyelés ahhoz a gondolathoz vezetett, hogy általánosan a városi agglomerációk és a fejlett régiók rendelkeznek a legmagasabb innovációs képességgel, anélkül, hogy ennek az evolúciós mechanizmusa meg lenne magyarázva (Malmberg és Maskell 2002).

$\mathrm{Az}$ ebben a részben felhasznált mutatók egyértelmúen jelzik, hogy - bár jelentős felsőoktatási kapacitással rendelkezik - Észak-Magyarország nem csak hogy nem tartozik a jelentősebb innovációs teljesítményt felmutató régiókhoz, hanem az minimálisan szinten sem adottak a feltételek egy regionális innovációs rendszer kialakulásának és müködésének. Amennyiben ezt tényként kezeljük, feltételezzük, hogy a társadalmi innováció sem jelentősebb ebben a régióban mint az innováció egyéb formái.

\section{Társadalmi innováció Észak-Magyarországon}

Az államilag irányított tervgazdaság időszakában a régió - elsősorban Borsod-Abaúj-Zemplén megye - a magyar fejlődési hierarchia felső szintjén pozicíonálódott, a térségi nyersanyagbázisra épülö extenzív iparosítás és urbanizáció eredményeként. A nehéziparra szakosodott gazdasági fejlődési ugyanakkor létrehozott egy olyan regionális intézményrendszert, amely a rendszerváltást követően képtelen volt radikálisan megújulni, alapvető innovációkat létrehozni. Gyakorlatilag a régió nagyobb városi központjait leszámítva elmaradt az átmenet a tudás-alapú, információs társadalomba. Az átmeneti, 1989-at követő időszakban számottevő, áttörő gazdaság változás nem történt, a magasan képzett munkaerő elvándorlása és a rossz politikai és szakpolitikai döntések 
miatt. Az Eurostat által rendszeresen közölt regionális fejlődési rangsorban Észak-Magyarország az elmúlt évtizedben folyamatosan a legszegényebb húsz régiója (NUTS-2) között szerepelt, a GDP volumenindexe alapján. A legfrissebb adatok szerint, 2018-ban, a régió az Európai Unió 14. legszegényebb térsége volt, egy főre eső, vásárlóerőparításon mért GDP-je Ennek eredményeként úgy látszik, hogy Észak-Magyarország tartósan az európai gazdasági térség perifériáján marad.

Mindez természetesen nem kedvező kiindulópont az innováció helyzetfelmérésében. Tulajdonképpen az innováció vizsgálatában két évtizeddel korábban kialakult irányváltás - amely a társadalmi innováció jelentőségét hangsúlyozta - némi reményt kínált a periférikus térségek számára is, mint egy olyan társadalmi újításokra vonatkozó innováció típus, amely egy adott helyi közösség jólétén javíthat, olyan társadalmi szükségleteket elégítve ki, amelyeket a piaci folyamatok nem képesek. Általánosan elfogadott az a szemlélet is, hogy a társadalmi innovációk olyan termékek vagy szolgáltatások, amelyeket nem a hagyományos piaci mechanizmusok hoznak létre, és hogy ezek, a maguk során, új együttmüködési formákat, társadalmi kapcsolatokat hoznak létre (Moulaert, MacCallum, Mehmood és Hamdouch 2013). Nagyon érdekes, hogy az utóbbi felfogást tükrözi néhány új, a területi tervezés, területfejlesztés irányából megjelenő kutatási eredmény, ahol új területfejlesztési politikák, stratégiák és ezek földrajzi mobilitása is társadalmi innovációként jelenik meg (Füg és Ibert 2020).

A társadalmi innováció iránti növekvő érdeklődést nyilvánvalóan táplálta az Európai Unió szakpolitikájának diverzifikációja és irányváltása, a Lisszaboni Szerződést követően. Ennek eredményeként az innováció támogatása, és ennek keretében a társadalmi innováció kiemelkedő helyet kaptak. Mérföldkőnek számit az Európai Bizottság által 2011-ben elindított „Társadalmi Innovációs Kezdeményezés" (Social Innovation Europe Initiative). Ilyen feltételek között indokolt a társadalmi innováció rendszeres vizsgálatának azon hulláma, amely a Miskolci Egyetem Gazdaságtudomány Karán alakult ki, és amelynek eredményeit két nagy kategóriába sorolhatjuk: a kutatások egy része azt tüzte ki céljául, hogy megvizsgálja a társadalmi innováció feltételeit Észak-Magyarország térségeiben (Nemes és Varga 2015; Benedek, Kocziszky és Veresné Somosi 2018; Lipták és Horváth 2018; Varga 2019; Kocziszky és Benedek 2019), míg másik része felmérte a térségek innovációs potenciálját (Kocziszky, Benedek és Veresné Somosi 2015; Kocziszky 2015; Benedek, Kocziszky, Veresné Somosi és Balaton 2016; Varga, Tóth és Nagy, 2020). A két irányzat fontos összegzését olvasni lehet egy nemrég megjelent tanulmánykötetben is (Sikos, 2020).

A térségi társadalmi innovációs potenciál mérésében elért eredményeket azért is jelentősek, mert nincs egy általánosan elfogadott szakmai konszenzus a mérés módszertanát és a felhasznált indikátorstruktúrát illetően. Így tehát gyakorlatilag a fent említett vizsgálatok hozzájárultak, egy jellegzetesen periférikus, kelet-európai kontextusban, a mérés módszertanának szakirodalmi bővítéséhez, az eredmények összehasonlíthatóságának javításához. Igazolódott újból, hogy a felhasznált indikátorok típusa és mennyisége a hivatalosan elérhető adatok függvénye, és ez erősen ingadozik egyes országok között. Például, Szendi Dóra tanulmányában (2018) sikeresen alkalmazta a magyarországi körülményekre a társadalmi innovációs potenciál mérésének az „Economist Intelligence Unit” (EUI) által kidolgozott összetett módszertanának logikai fonalát (Economist Intelligence Unit, 2016), ahol a társadalmi innovációs indexnek négy alapvető összetevőjét határozzák meg: politikai és intézményi keretek, finanszírozás, vállalkozások, társadalom. Az EUI index érdekessége nem annyira a skálázás és normalizáció jellegében jelentkezik, hanem az egyes komponensek súlyozásában, sorrendben: 44,4\%, 22,2\%, $15 \%$, illetve 18,3\%. Érdekességként megjegyzendő, hogy az EUI index alapjána társadalmi innováció szoros statisztikai összefüggést mutat a gazdasági teljesítménnyel, ami homlokegyenest ellentmond a szakirodalom egy másik általánosan elfogadott feltételezésével, amelyre már utaltam korábban e tanulmányban is, éspedig hogy a társadalmi innováció a periférikus térségek számára egy kitörési lehetőséget nyújtana. Egyéb jelentős vizsgálatokban is kimutatták a fenti szoros összefüggést, így például a korábban már említett Európai Innovációs Eredménytábla innováció indexe szorosan összefügg a gazdasági fejlettség szintjével, az egy főre jutó GDP-vel (EB, 2019). 
Az Észak-magyarországi települések társadalmi innovációs potenciáljának mérését végül a szerző egy érdekes kétlépcsős modellben oldja meg módszertanilag (eb.). Az első lépcsőben, öt indikátor felhasználásával meghatározza minden település gazdasági térben elfoglalt helyét, különös figyelemmel a periférikus helyzetben lévő településekre. A második fázisban, három mutatóval kerül mérésre a társadalmi innovációs potenciál: szász före jutó nonprofit szervezetek száma, száz főre jutó társadalmi vállalkozások száma és a szász före jutó közigazgatásban foglalkoztatottak száma. Érdekes, hogy míg az első és harmadik mutató értékei a régió északi és északkeleti periférikus térségeiben mutatnak nagyobb fajlagos súlyt, addig a társadalmi vállalkozások a gazdaságilag fejlettebb magterületeken koncentrálódnak. Végül sor került annak vizsgálatára, hogy megállapítható-e egy összefüggés egy település gazdasági hátrányos helyzete és a társadalmi innovációs alapfeltételek meglét között (eb.). A kapcsolat gyenge, de statisztikailag szignifikáns. Ez azt jelenti, hogy minél több gazdasági vagy társadalmi probléma halmozódik fel egy településen, annál jobb társadalmi innovációs feltételekkel rendelkezik. Ez egy érdekes és értékes eredmény, amelynek igazolására további empirikus vizsgálatokra és a fogalmi, elméleti keretek, kapcsolatok részletezésére, a hatásmechanizmusok pontos vizsgálatára és leírására lesz szükség. További Borsod-Abaúj-Zemplén megyére elvégzett esettanulmányok, részben azonos indikátorokkal, igazolták a fenti megállapításokat, bár a legjelentősebb társadalmi innovációs potenciállal rendelkező települések rangsora némileg eltér (Varga, Tóth és Nagy, 2020). Ez ismét nem csupán a módszerek és indikátorok további validálásának a szükségességét vetítik elöre, hanem a mögöttük levő, elméleti megalapozottságú megértését is.

\section{Konklúziók, kitekintés - innováció és fenntartható fejlődés}

Összefoglaló tanulmányunkban két irányban haladtunk: az innovációkutatás elméleti kereteitől az empirikus vizsgálatok irányába, illetve a makroszinten müködö, a központi kormányzat tudomány - pénzügyi rendszer - ipari szereplők közötti kapcsolódások eredményeként müködő országos vagy nemzeti innovációs keretrendszertől a regionális innovációs rendszerek irányába. Az utóbbikat az innováció földrajzára jellemző térbeli differenciálódásra hangsúlyt tevő összehasonlítás alapján próbáltuk beazonosítani. A fővárosi agglomeráció mellett, attól jelentősen lemaradva, néhány regionális innovációs rendszer müködése megkérdőjelezhetetlen. Ezek Csongrád, Hajdú-Bihar és Veszprém megyéknek felelnek meg, mindegyik, de különösen az első kettő, jelentős katalizátor szerepet játszó egyetemi központokkal, illetve az innovációban jelentős ipari szereplőkkel. Észak-Magyarország ezekkel az - magyarországi összehasonlításban innovatív régiókkal nem versenyezhet sem innovációs teljesítmény, sem innovációs feltételek és potenciál tekintetében. Kitértünk arra a tényre, hogy a társadalmi innováció egymagában nem jelent kitörési lehetőséget sem az innováció, sem a gazdasági növekedés tekintetében. Számos esettanulmány viszont azt bizonyítja, hogy a társadalmi innováció elszigetelten, lokális szinten, bizonyos településeken képes új vagy újszerü megoldásokat nyújtani a felhalmozódott helyi problémák egy részének megoldására. További lényeges összegző megállapítás arra vonatkozik, hogy bár a nagyszámú esettanulmányok világosan bizonyították a statisztika eszközeivel a használt indikátorok közötti kapcsolatok erösségét, még távol tartunk attól, hogy átütő módon megértsük a társadalmi innováció müködési- és hatásmechanizmusát. Ezen a területen további kutatások és vizsgálatok szükségesek. Továbbá érdemes a periférikus régiók esetében, így ÉszakMagyarország esetében is, a külső faktorok szerepével foglalkozni: nem-e tudja ez a térség a belső innovációs tényezőszűkösségét külső kapcsolataival bizonyos mértékben kompenzálni: ebben az értelmezési keretben úgy a többi magyar régióval, elsősorban Budapesttel, kialakult interregionális kapcsolatok, mint a nemzetközi együttmüködési kapcsolatok is fontos szerepet tölthetnek be.

Végezetül, mintegy új jelenségként utalunk azokra a kutatási eredményekre, amelyek azért érvelnek, hogy elkerülhetelenné válik - a koronavírus járvány hatására is - az innováció minden formáját alárendelni a fenntartható fejlődési céloknak (Nagy, Benedek és Ivan, 2018; Ivan 
és társai, 2020). Az utóbbiakat, mint tudjuk, egy jelentős nemzetközi együttműködés eredményeként az Egyesült Nemzetek Szervezetének Közgyülése fogalmazott meg 2015-ben, amikor egyhangúan elfogadott egy új integrált fenntartható fejlődési és fejlesztési keretrendszert, az Agenda 2030 a Fenntartható Fejlödésért címmel. Az új keretrendszer fö jellegzetessége, hogy komplexebb és átfogóbb mint a korábbi fejlesztési együttmüködési keretek, a környezeti dimenzió mellett magába foglal egy gazdasági és egy szociális dimenziót is. Az Agenda magját a Fenntartható Fejlódési Célok (FFC) teszik ki, amelyek, újabb nóvumként, nem csupán globális szinten vannak meghatározva, hanem minden ország, régió és település számára feladatokat írnak elő. A 2030-ig minden tagállam által felvállalt 17 FFC a következő: 1. a szegénység felszámolása, 2. az éhezés megszüntetése, 3. egészség és jólét, 4. minőségi oktatás, 5. nemek közötti egyenlőtlenség, 6. tiszta víz és alapvető köztisztaság, 7. megfizethető és tiszta energia, 8. tisztességes munka és gazdasági növekedés, 9. ipar, innováció és infrastruktúra, 10. egyenlőtlenségek csökkentése, 11. fenntartható városok és közösségek, 12. felelős fogyasztás és termelés, 13. fellépés az éghajlatváltozás ellen, 14. óceánok és tengerek védelme, 15. szárazföldi ökoszisztémák védelme, 16. béke, igazság és erős intézmények 17. partnerség a fenntartható fejlődésért. A fenti 17 célon belül további 169 részcélt fogalmaz meg az Agenda 2030. A célok monitorizálásához 230 indikátort határoztak, eredetileg. Azért eredetileg, mert a 230 indikátort országok szintjén jelölték ki, és - amint utólag kiderült - ezek jelentős része helyi szinten nem elérhető, ezért újabb indikátorokra meghatározásának szükségessége merült fel.

Mazzucato és társai ezen céloknak rendelné alá a következő évek $\mathrm{K}+\mathrm{F}$ kiadásait, célorientált, nagyobb összgazdasági hatást kifejtő kutatások és fejlesztések formájában (Mazzucato, Kattel és Ryan-Collins, 2020). Ezek új dinamikus innovációs rendszereket képesek létrehozni, amelyek nem csupán egyes iparágakra fejtenének ki pozitív hatást, hanem az egész gazdaságra. Érdemes fontolóra venni ezt az elképzelést.

Köszönetnyilvánítás. A kutatás az EFOP-3.6.1-16-2016-00011 jelü „Fiatalodó és Megújuló Egyetem - Innovativ Tudásváros - a Miskolci Egyetem intelligens szakosodást szolgáló intézményi fejlesztése" projekt részeként - a Széchenyi 2020 keretében - az Európai Unió támogatásával, az Európai Szociális Alap társfinanszirozásával valósult meg".

\section{Irodalomjegyzék}

BENEDEK, J. (2004): Amenajarea teritoriului şi dezvoltarea regională. Cluj-Napoca: Presa Universitară Clujeană/Kolozsvári Egyetemi Kiadó.

BENEDEK, J. (2006): Területfejlesztés és regionális fejlődés. Cluj-Napoca: Presa Universitară Clujeană/Kolozsvári Egyetemi Kiadó.

BENEDEK, J. (2019): AZ INNOVÁCIÓ FÖLDRAJZA. IN: EMBER-TÉR-IDÖ. (SZERK.: SEBESTYÉNNÉ DR. SZÉP T., NAGY Z.) MisKOlC: BÍBOR Kiadó, 32-42.

BENEDEK, J., KOCZISZKY, GY. (2017): TERÜLETI POLARIZÁCIÓ ÉS KONVERGENCIA A VISEGRÁDI ORSZÁGOKBAN, MAGYAR TUDOMÁNY. 178:3, 261-272.

BENEDEK, J., LEMBCKE, A. (2017): CHARACTERISTICS OF RECOVERY AND RESILIENCE IN THE ROMANIAN REGIONS. EASTERN JOURNAL OF EUROPEAN STUDIES. 8:2. 95-126.

BENEDEK, J., KOCZISZKY, GY., VERESNÉ SOMOSI, M., BALATON, K. (2016): Generating and Measuring Regional Social Innovation. Club of Economics Miskolc TMP, 12, special issue. 14-25.

BENEDEK, J., KOCSZISZKY, GY., VERESNÉ SOMOSI, M. (2018): AZ INNOVÁCIÓ VIZSGÁLATÁNAK ELMÉLETI ÉS GYAKORLATI KÉRDÉSEI: TECHNOLÓGIAI INNOVÁCIÓTÓL TÁRSADALMI INNOVÁCIÓIG. ERDÉLYI TÁRSADALOM, 16:2. 11-30. 
BENEDEK J., SEBESTYÉN T., BARTÓK B. (2018): EVALUATION OF RENEWABLE ENERGY SOURCES IN PERIPHERAL AREAS AND RENEWABLE ENERGY-BASED RURAL DEVELOPMENT. RENEWABLE AND SUSTAINABLE ENERGY REVIEWS, 90:7, 516-535.

BELUSZKY, P. (2019): BORSOD-ABAÚJ-ZEMPLÉN MEGYE „FOGYÓ FÉLHODJA”. ÉSZAKMAGYARORSZÁGI STRATÉGIAI FÜZETEK, 16:2, 5-21.

CEBOTARI, S., BENEDEK, J. (2017): RENEWABLE ENERGY PROJECT AS A SOURCE ON INNOVATION IN RURAL COMMUNITIES. SUSTAINABILITY, 9:4. 509.

DŐRY, T., RECHNITZER, J. (2000): REGIONÁLIS INNOVÁCIÓS STRATÉGIÁK. BUDAPEST: OKTATÁSI MINISZTÉRIUM.

DŐRY, T. (2005): Regionális innováció-politika. Budapest-Pécs: Dialóg Campus Kiadó.

ECONOMIST INTELLIGENCE UNIT (2016): Old problems, new solutions: measuring the capacity for social innovation across the world,

https:/eiuperspectives.economist.com/sites/default/files/Social_Innovation_Index.pdf. Letöltve: 2020.11.05.

EDER, J. (2018): Innovation in the periphery: a critical survey and research agenda. International Science Review, 42:2, 119-146.

EURÓPAI BIZOTTSÁG (2019): A 2019. évi innovációs eredménytábla, https://ec.europa.eu/commission/presscorner/detail/hu/IP $192991 . \quad$ Letöltve: 2020.11.04.

FITJAR, R.D., RODRÍGUEZ-POSE, A. (2020): Where cities fail to triumph: the impact of urban location and local collaboration on innovation in Norway. Journal of Regional Science, 60:1, 5-32.

GRAFFENBERGER, M., VONNAHME, L., BRACHERT, M., LANG, T. (2019): Broadening pesrpectives: innovation outside of agglomerations. In: Koschatzky, K., Stahlecker, T. (eds.): Innovation based regional change in Europe: Chances, risks and policy implications, 47-68. Karlsruhe: Fraunhofer.

IVAN K., HOLOBÂCĂ I.H., BENEDEK J., TÖRÖK I. (2020) Potential of Night time lights to measure regional inequality. Remote Sensing, 12:1, 33.

KARAJZ, S., KIS-ORLOCZKI, M. (2019): The relationship between sustainable development and social innovation in Hungary, and in the Visegrád countries. In: Nagy K., Piskóti I. (eds.): Reconnecting Asia with Eastern Europe. MAG Scholar Conference in Business, Marketing and Tourisam. Miskolc: Institute of Marketing and Tourism, University of Miskolc, 29-46.

KOCZISZKY, GY. (2015): Társadalmi innováció mérésének sajátosságai, In: „Mérleg és Kihívások” IX. Nemzetközi Tudományos Konferencia. (szerk.: Veresné dr. Somosi M., Lipták K.) Miskolc-Lillafüred: Miskolci Egyetem, Gazdaságtudományi Kar.

KOCZISZKY, GY. (2021): Észak-Magyarország (kézirat, megjelenés alatt).

KOCZISZKY, GY., BENEDEK, J., VERESNÉ SOMOSI, M. (2015): Új innovációs paradigma? Regionális társadalmi innovációs potenciál javításának lehetősége szakértői rendszer segítségével, lehetőségek és korlátok. In: „Mérleg és Kihívások” IX. Nemzetközi Tudományos Konferencia. (szerk.: Veresné dr. Somosi M., Lipták K.) MiskolcLillafüred: Miskolci Egyetem, Gazdaságtudományi Kar, 247-254.

KOCZISZKY, GY., BENEDEK, J. (2019): CONTRIBUTIONS TO THE IMPACT ASSESSMENT OF NETWORK COOPERATION AMONG SOCIAL ENTERPRISES. CLUB OF ECONOMICS MISKOLC TMP, 15:2. 23-28.

KOCZISZKY, GY., SZENDI, D. (2018): Regional Disparities of the Social Innovation Potential in the Visegrad Countries: Causes and Consequences. European Journal of Social Sciences Education and Research, 12:1. 35-41.

LENGYEL, I., RECHNITZER, J. (2004): Regionális gazdaságtan. Budapest-Pécs: Dialóg Campus Kiadó.

LIPTÁK, K., HORVÁTH, K. (2018): Társadalmi innovációk szerepe a foglalkoztatáspolitikában és a vidékfejlesztésben. Észak-magyarországi Stratégiai Füzetek, 15:3. 55-68. 
LIPTÁK, K., SZENDI, D., MUSINSZKI, Z. (2019): Munkaerő-piaci folyamatok elemzése az Abaúji térségben. Észak-magyarországi Stratégiai Füzetek, 15:3. 22-30.

MALMBERG, A., MASKELL, P. (2002): The elusive concept of localization economies: towards a knowledge-based theory of spatial clustering. Environment and Planning, 34, 429-449.

MAZZUCATO, M., KATTEL, R., RYAN-COLLINS, J. (2020): Challenge-driven innovation policy: towards a new policy toolkit. Journal of Industry, Competition and Trade. 20, 421-437.

MOUlaERT, F., MACCAllum, D., MEHMOOD, A., HAMdOUCH, A. (2013): The international handbook of social innovation. Collective action, social learning and transdisciplinary research. Cheltenham: Edward Elgar.

NAGY J., BENEDEK J., IVAN K., (2018) Measuring Sustainable Development Goals at local level. A case of a metropolitan area in Romania, Sustainability, 10:11, 3962

NEMES, G., VARGA, Á. (2015): Társadalmi innováció és társadalmi tanulás a vidékfejlesztésben - sikerek, problémák, In: „Mérleg és Kihívások” IX. Nemzetközi Tudományos Konferencia, Konferencia Kiadvány (szerk.: Veresné Somosi M., Lipták, K.) MiskolcLillafüred: Miskolci Egyetem, Gazdaságtudományi Kar, 434-444.

SCHUMPETER, J.A. (1912., 1980): A gazdasági fejlődés elmélete. Vizsgálódás a vállalkozói profitról, a tôkéről, a hitelről, a kamatról és a konjunktúraciklusról. Budapest: Közgazdasági és Jogi Könyvkiadó.

SIKOS, T., T. (2020): Társadalmi innováció - Társadalmi jólét. Budapest (kézirat, megjelenés alatt).

SZENDI, D. (2018): A társadalmi innovációs potenciál mérésének lokális szintű lehetőségei, Erdélyi Társadalom, 16:1.31-58.

VARGA, K., TÓTH, G., NAGY, Z. (2020): Examination of social innovation potential characteristics in the example of County, Theory Methodology and Practice: Club of Economics in Miskolc, 16:1. 65-76.

VARGA, K. (2019): Társadalmi innovációs törekvések megvalósítási lehetőségei az Abaúji térségben, Észak-magyarországi Stratégiai Füzetek, 16:2. 73-86.

VARGA, A., SEBESTYÉN, T. (2015): Innováció Kelet-Közép-Európában. Közgazdasági Szemle, LXII (Szept.), 881-908. 